\title{
UJI AKTIVITAS ANTI JAMUR EKSTRAK INFUSA DAUN SIRSAK (Annona muricata L.) TERHADAP Candida albicans
}

\author{
${ }^{1}$ MIFTACHUL SOBIRIN \\ ${ }^{1}$ Stikes Borneo Cendekia Medika Pangkalan Bun \\ ${ }^{1}$ Email: miftachul_sob@yahoo.co.id
}

\begin{abstract}
ABSTRAK
Kandidiasis adalah suatu penyakit jamur, yang bersifat akut atau sub akut disebabkan oleh Candida albicans dapat menyerang daerah kulit, mulut, selaput mukosa vagina, kuku, bronki atau paru-paru. Penyakit ini ditemukan di seluruh dunia dan dapat menyerang semua umur baik laki-laki maupun perempuan. Pengetahuan tentang obat merupakan warisan budaya bangsa salah satunya jenis tanaman berkhasiat obat daun sirsak terhadap Candida albicans. Penelitan dengan metode true eksperimental, Populasi daun sirsak (Annona Muricata L.), diperoleh dari daerah Pasir Panjang, Pangkalan Bun, Kal-Teng. Jamur uji yang digunakan dalam penelitian ini adalah jamur Candida albicans. Medium yang digunakan dalam penelitian ini adalah medium SGA (Sabouraud Glucose Agar) + khloramfenikol 75 ppm dan medium SGC (Sabouraud Glucose Cair). Daun sirsak yang digunakan adalah daun yang berasal dari tanaman sirsak dewasa. Pengujian anti jamur dilakukan dengan metode dilusi atau seri pengenceran dengan interval pengenceran dua kali, menggunakan 12 tabung reaksi, tiap tabung dimasukkan sebanyak 0,5 $\mathrm{ml}$ SGC secara aseptis. Semua tabung diinkubasi selama 5-7 hari pada suhu kamar, kemudian diamati adanya pertumbuhan (kekeruhan) dengan cara membandingkan dengan kontrol negatif dan kontrol positif. Hasil Penelitian yaitu Infusa daun sirsak mempunyai aktivitas untuk menghambat dan membunuh pertumbuhan jamur Candida albicans yang menunjukkan KHM dan KBM pada konsentrasi $12,5 \%$.
\end{abstract}

Kata Kunci : Aktivitas, Infusa, Daun Sirsak, Candida albicans.

\section{ANTI-FUNGUS ACTIVITY TEST OF SIRSAK (Annona muricata L.) LEAF INFUSION EXTRACT ON Candida albicans}

\begin{abstract}
ABSTRACK
Candidiasis is a fungal disease, which is acute or sub-acute caused by Candida albicans which can attack the skin, mouth, mucous membranes of the vagina, nails, bronchi or lungs. This disease is found throughout the world and can affect all ages both men and women. Knowledge about medicine is a cultural heritage of the nation one of them is a type of medicinal plant soursop leaf medicinal against Candida albicans. Research with true experimental method, Soursop leaf population (Annona Muricata L.), obtained from the Pasir
\end{abstract}


Panjang area, Pangkalan Bun, Kal-Teng. The fungus used in this research was Candida albicans. The medium used in this research was SGA (Sabouraud Glucose Agar) + 75 ppm chloramphenicol medium and SGC (Sabouraud Glucose Liquid) medium. Soursop leaves used are leaves that come from adult soursop plants. Antifungal testing was carried out by dilution method or dilution series with dilution intervals twice, using 12 test tubes, each tube was inserted as much as $0.5 \mathrm{ml} \mathrm{SGC}$ aseptically. All tubes were incubated for 5-7 days at room temperature, then observed growth (turbidity) by comparing with negative controls and positive controls. The results of the study are soursop leaf infusion which has activity to inhibit and kill the growth of the fungus Candida albicans which shows the MIC and MBC at a concentration of $12.5 \%$.

Keywords: Activity, Infusion, Soursop Leaves, Candida albicans.

\section{PENDAHULUAN}

Sejak jaman dahulu masyarakat Indonesia telah mengenal dan menggunakan tanaman berkhasiat obat sebagai penanggulangan masalah kesehatan. Pengetahuan tentang obat ini merupakan warisan budaya bangsa sebelum pelayanan kesehatan dengan obat-obatannya menyentuh masyarakat (Kusuma dkk., 1992).

Dari sekian banyak jenis tanaman berkhasiat obat yang ada, dipilihlah penelitian tentang daun sirsak terhadap Candida albicans. Dalam hal ini, bagi sebagian masyarakat Indonesia tumbuhan sirsak (Annona muricata L.) masih belum banyak literatur maupun penelitian ilmiah yang mengungkapkan khasiatnya. Maka daun sirsak cenderung kurang di manfaatkan secara optimal dibandingkan penggunaan buahnya yang sering dimanfaatkan secara komersil. Banyak juga masyarakat yang akhirnya menganggap daun sirsak sebagai sampah yang tidak memiliki kegunaan. Namun penelitian terbaru memberikan data empiris bahwa masyarakat dapat memanfaatkannya untuk proses penyembuhan berbagai penyakit. Karena hampir semua bagian tumbuhan ini bermanfaat, khususnya daunnya yang mengandung tanin, fitosterol, kalsium oksalat dan alkaloid murisine (Thomas, 1992).

Kandidiasis banyak menyerang masyarakat di daerah tropis seperti Indonesia, hal ini disebabkan Indonesia memiliki curah hujan yang tinggi dan kelembapan yang tinggi sehingga pertumbuhan jamur menjadi sangat baik. Kandidiasis adalah suatu penyakit jamur, yang bersifat akut atau sub akut disebabkan oleh Candida albicans. Candida albicans yang dapat 
diisolasi dari kulit, mulut, selaput mukosa vagina atau feses orang normal dan dapat menyerang daerah kulit, mulut, selaput mukosa vagina, kuku, bronki atau paru-paru. Penyakit ini ditemukan di seluruh dunia dan dapat menyerang semua umur baik laki-laki maupun perempuan (Suprihatin, 1982).

Penelitan terhadap daun sirsak sebagai alternatif pengobatan jamur sangat menarik untuk mengetahui kebenaran mengenai manfaatnya sebagai antijamur. Penelitiannya yaitu dengan cara membuat ekstrak infusa daun sirsak. Peneliti tertarik untuk meneliti bagaimana aktivitas daun sirsak sebagai obat antijamur khususnya Candida albicans.

\section{Jamur}

Jamur adalah tumbuhan yang berinti, berspora, tidak berklorofil, berupa sel atau benang, dengan dinding dari selulosa atau kitin, atau dari keduanya, dan pada umumnya berkembang biak secara aseksual dan seksual dan mempunyai bagian tubuh berbentuk filamen-filamen dan sebagian lain berbentuk uniseluler (Dwidjoseputro, 1976)

\section{Morfologi}

Jamur terdiri dari khamir dan kapang, khamir yaitu sel-sel yang berbentuk bulat, lonjong, atau memanjang yang berkembang biak dengan menggunakan tunas dan membentuk koloni yang basah atau berlendir. Khamir yang membentuk tunas yang memanjang yang bertunas lagi pada ujungnya secara terus menerus, sehingga berbentuk seperti hifa dengan penyempitan pada sekat-sekat dan disebut hifa semu. Anyaman dari hifa semu disebut miselium semu.

Kapang yang terdiri dari selsel memanjang dan bercabang yang disebut hifa. Hifa tersebut dapat bersekat sehingga terbagi menjadi banyak sel atau tidak bersekat dan disebut hifa senositik, anyaman hifa baik yang multiseluler atau senositik disebut miselium. Kapang membentuk koloni yang menyerupai kapas dan padat. Bentuk khamir atau kapang tidak mutlak karena terdapat jamur yang dapat membentuk kedua sifat tersebut dalam keadaan berbeda dan disebut sebagai jamur dimorfik (Dwidjoseputro, 1976).

\section{Fisiologi}

Jamur dapat lebih bertahan hidup dalam keadaan yang tidak menguntungkan dibandingkan dengan jasad-jasad renik yang lain. Jamur dapat hidup pada pH 3,8 - 5,6. Khamir bersifat fakultatif yang artinya dapat hidup dalam keadaan aerobik maupun anaerobik. Kapang 
adalah mikroorganisme aerobik sejati yang dapat hidup dalam kisaran suhu $22-30^{\circ} \mathrm{C}$ (saprofit) dan $0-37^{\circ} \mathrm{C}$ (parasit). Jamur dapat hidup dalam kadar gula 4-5\%, resisten terhadap penicilin, tetrasiklin, kloramfenikol dan peka terhadap griseovultin (Pelzcar dan Chan, 1986).

\section{Reproduksi}

Secara alamiah jamur berkembang biak dengan berbagai cara, baik secara aseksual dengan pembelahan, penguncupan atau pembentukan spora. Dapat pula secara seksual dengan peleburan nukleus dari dua sel induk. Pada pembelahan suatu sel membagi diri untuk membentuk dua sel anak tumbuh dari penonjolan kecil dari sel inang (Pelczar dan Chan, 1986).

Perkembangbiakan jamur secara aseksual dapat berlangsung dengan cara jamur bersel satu berbiak dengan membelah diri atau dengan bertunas (blastospora), sepotong miselium atau sepotong hifa dapat melanjutkan kehidupan koloni, pembiakan secara aseksual disebut fragmentasi, jamur menghasilkan konidia yaitu ujung hifa-hifa tertentu yang membagi-bagi diri menjadi bentuk-bentuk yang bulat atau serupa telur atau yang serupa empat persegi panjang
Perkembangbiakan secara seksual memerlukan dua jenis jamur yang cocok, artinya yang dapat kawin. Proses perkawinan antara 2 jenis yang kompatibel pada hakekatnya terdiri atas persatuan antara dua protoplast yang kemudian diikuti dengan persatuan intinya. Jamur yang berinti satu haploid dan oleh karena itu tidak dapat mengadakan perkawinan sendiri, maka jamur itu dinamakan heterotalik mandul. Jadi jamur itu hanya dapat berkawin dengan jenis lain yang kompatibel. Jamur yang berinti dua (atau banyak) tak sama dan karena itu dapat mengadakan perkawinan sendiri disebut hemotalik subur (Dwidjoseputro, 1976).

\section{METODOLOGI PENELITIAN}

\section{Tempat dan Waktu Penelitian}

Tempat Laboratorium Mikrobiologi, D-III Analis Kesehatan STIKes BCM dan Waktu pelaksanaan penelitian pada tahun 2017

\section{Bahan atau Materi Penelitian}

Populasi daun sirsak yang digunakan dalam penelitian ini adalah tanaman sirsak (Annona Muricata L.), diperoleh dari daerah Pasir Panjang, Pangkalan Bun, KAL-TENG.

\section{Sampel}


Daun sirsak yang digunakan adalah daun yang diambil dari tanaman dewasa, karena pada usia panen tersebut zat-zat metabolit dalam daun optimal. Daun sirsak diperoleh dari daerah Pasir Panjang, Pangkalan Bun, KAL-TENG.

\section{Jamur Uji}

Jamur uji yang digunakan dalam penelitian ini adalah jamur Candida albicans yang diperoleh dari Laboratorium Mikologi UGM.

\section{Medium}

Medium yang digunakan dalam penelitian ini adalah medium SGA (Sabouraud Glucose Agar) + khloramfenikol 75 ppm dan medium SGC (Sabouraud Glucose Cair). Medium ini diperoleh dari Laboratorium Mikrobiologi Prodi D-III Analis Kesehatan, STIKes Borneo Cendekia Medika Pangkalan Bun.

\section{Alat Penelitian}

Alat yang perlu disiapkan adalah Panci infusa, Cawan petri, Pipet ukur, Lampu spirtus, Bola karet, Penyaring (kain flanel), Erlenmayer, Penangas air, Pisau, Entkas, Jarum ose dan Tabung reaksi

\section{Prosedur Kerja}

\section{Identifkasi Jamur Uji}

Identifikasi jamur Candida albicans dilakukan pada medium Sabouraud Glucose Agar yang dieramkan pada suhu kamar 1-2 hari akan terbentuk koloni-koloni lunak yang berwarna krem dan berbau seperti ragi. Biakan Candida muda akan membentuk germ tube bila diletakkan dalam serum selama 3 jam pada suhu $37^{\circ} \mathrm{C}$.

\section{Pemetikan Daun Sirsak}

Daun sirsak yang digunakan adalah daun yang berasal dari tanaman sirsak dewasa. Daun yang dipakai merupakan daun yang dewasa karena kandungan metabolitnya maksimal. Pemetikan sebaiknya dilakukan dengan menggunakan gunting, dipotong pada bagian pangkal daun.

\section{$\underline{\text { Pembuatan Infusa }}$}

Daun sirsak yang sudah dipetik kemudian dicuci dengan air mengalir, kemudian dirajang halus dengan pisau. Ditimbang 50 gram daun yang telah dirajang kemudian diletakkan dalam panci infus bagian dalam. Pada panci infus bagian luar diberi air sampai setengah bagian atau lebih. Daun sirsak yang terdapat dalam panci ditambah dengan air sebanyak $100 \mathrm{ml}$ lalu panaskan selama 15 menit terhitung mulai mencapai suhu $90-98^{\circ} \mathrm{C}$ sambil sekali-kali diaduk. Saring selagi panas melalui kain flanel, kemudian ditambahkan air panas melalui ampas sampai volume yang dikehendaki (Hutapea, 1991).

\section{Pembuatan Suspensi jamur uji}


Diambil beberapa ose biakan Candida albicans, dimasukkan dalam tabung reaksi yang berisi $10 \mathrm{ml}$ garam fisiologis. Campuran dikocok hingga homogen, disetarakan Standart Brown 11. Suspensi yang didapat diencerkan 1 : 1000 dengan larutan garam fisiologis steril. Hasil pengenceran digunakan untuk pengujian anti jamur.

\section{Pengujian Anti Jamur}

Pengujian anti jamur dilakukan dengan metode dilusi atau seri pengenceran dengan interval pengenceran dua kali. Disiapkan 12 tabung reaksi, kemudian tiap tabung dimasukkan sebanyak $0,5 \mathrm{ml}$ SGC secara aseptis. Tabung 1 diisi $1 \mathrm{ml}$ infusa, dikocok. Sebanyak $1 \mathrm{ml}$ dari tabung 1 dipindahkan ke tabung 2, kocok. Perlakuan sama juga dilakukan untuk tiap tabung berikutnya sampai tabung 11. Ditambahkan 0,5 ml jamur uji (Candida albicans) yang telah diencerkan 1:1000 pada semua tabung kecuali tabung 11 . Tabung terakhir sebagai kontrol positif sedangkan tabung 11 sebagai kontrol negatif. Semua tabung diinkubasi selama 5-7 hari pada suhu kamar, kemudian diamati adanya pertumbuhan (kekeruhan) dengan cara membandingkan dengan kontrol negatif dan kontrol positif.

Menentukan KHM (Konsentrasi Hambatan Minimal) berdasarkan tabung reaksi yang tidak menunjukan kekeruhan dapat diamati secara visual. Untuk mengetahui dan membedakan lebih pasti KHM (Konsentrasi Hambatan Minimal) dan KBM (Konsentrasi Bunuh Minimal) diperlukan inokulasi pada medium SGA (Saboroud Glukosa Agar) dalam cawan petri dan diinkubasi pada suhu kamar selama 1-2 hari. KBM (Konsentrasi Bunuh Minimal) ditunjukkan dengan tidak adanya pertumbuhan jamur pada medium SGA (Saboroud Glukosa Agar) dalam cawan petri.

Jika dibandingkan antara kekeruhan dalam tabung reaksi dengan pertumbuhan koloni dalam cawan petri, maka dapat ditentukan dan dapat dibedakan antara KHM (Konsentrasi Hambatan Minimal) dan KBM (Konsentrasi Bunuh Minimal).

Konsentrasi infusa yang berasal dari $100 \%$ menjadi: $50 \%$ pada tabung nomor 1 , konsentrasi $25 \%$ pada tabung nomor 2 , konsentrasi $12,5 \%$ pada tabung nomor 3 , konsentrasi $6,25 \%$ pada tabung nomor 4 dan seterusnya. Pada tabung nomor 11 digunakan sebagai kontrol negatif dan tabung nomor 12 digunakan sebagai kontrol positif (Anonim, 2006).

\section{HASIL DAN PEMBAHASAN}

\section{Hasil Pengujian Anti Jamur}


Pada penelitian ini dilakukan pengujian aktivitas infusa daun sirsak terhadap jamur Candida albicans dengan metode dilusi. Infusa daun sirsak dibuat dengan konsentrasi $50 \% ; 25 \% ; 12,5 \% ; 6,25 \% ; 3,13 \%$; $1,56 \% ; 0,79 \% ; 0,40 \% ; 0,20 \%$; dan $0,10 \%$.

Suspensi jamur yang digunakan disesuaikan kekeruhannya dengan Standard Brown II yang telah diencerkan dengan garam fisiologis 1000 kali. Ada atau tidaknya aktivitas

Tabel 1. Hasil Penelitian KHM dan KBM Infusa Daun Sirsak terhadap Jamur Candida albicans

\begin{tabular}{cccc}
\hline No & $\begin{array}{c}\text { Konsentrasi } \\
\text { Infusa Daun } \\
\text { Sirsak }\end{array}$ & $\begin{array}{c}\text { Kekeruhan suspensi jamur } \\
\text { pada tabung reaksi }\end{array}$ & $\begin{array}{c}\text { Penelitian } \\
\text { Inokulasi suspensi jamur pada } \\
\text { medium SGA }\end{array}$ \\
\hline 1 & $50 \%$ & Jernih & Tidak tumbuh \\
2 & $25 \%$ & Jernih & Tidak tumbuh \\
3 & $12,5 \%$ & Jernih & Tidak tumbuh \\
4 & $6,25 \%$ & Keruh & Tumbuh \\
5 & $3,13 \%$ & Keruh & Tumbuh \\
6 & $1,56 \%$ & Keruh & Tumbuh \\
7 & $0,79 \%$ & Keruh & Tumbuh \\
8 & $0,40 \%$ & Keruh & Tumbuh \\
9 & $0,20 \%$ & Keruh & Tumbuh \\
10 & $0,10 \%$ & Keruh & tumbuh \\
11 & Kontrol & Jernih & Tidak tumbuh \\
& Negatif & Keruh & Tumbuh \\
\hline
\end{tabular}

\section{Keterangan :}

1. Pada kolom kekeruhan suspensi jamur pada tabung reaksi dapat diamati ada atau tidaknya aktivitas anti jamur dilihat dari tingkat kekeruhan pada tabung percobaan.

2. Pada kolom inokulasi suspensi jamur pada medium SGA dapat diamati ada anti jamur dapat dilihat dari tingkat kekeruhan pada tabung percobaan yang kemudian ditetapkan sebagai Konsentrasi Hambat Minimal (KHM), kemudian dari hasil tersebut pada tabung yang jernih dilakukan goresan untuk ditetapkan sebagai Konsentrasi Bunuh Minimal (KBM). Hasil penelitian yang diperoleh adalah sebagai berikut : 
4. Tabung 12 adalah kontrol positif, berisi medium SGC dan suspensi jamur Candida albicans.

\section{Pembahasan}

Penyarian yang digunakan dalam penelitian ini adalah dengan pembuatan infusa, pembuatan infusa adalah dengan merebus daun sirsak dengan menggunakan panci infusa selama 15 menit terhitung mulai dari suhu $90^{\circ} \mathrm{C}$, larutan penyari yang digunakan adalah air maka senyawa senyawa yang larut dalam air saja.

Kelebihan dari metode ini selain pembuatannya singkat dan cepat, alat dan bahan yang digunakan tidak terlalu banyak dan mudah didapat. Kekurangan dari metode ini adalah air sebagai pelarut penyari menyebabkan kemungkinan zat aktif yang tersari tidak sempurna.

Medium yang digunakan dalam penelitian ini adalah medium SGA yang ditambahkan khloramfenikol 75 ppm. Karena medium SGA mengandung pepton sebagai sumber makanan untuk pertumbuhan jamur Candida albicans, glukosa adalah sumber energi untuk jamur Candida albicans dan khloramfenikol merupakan antibiotik berfungsi untuk menghambat pertumbuhan bakteri.

Faktor yang mempengaruhi pertumbuhan jamur antara lain adalah suhu. Suhu inkubasi yang digunakan dalam penelitian ini adalah suhu kamar. Karena jamur Candida albicans bersifat mesofilik, yaitu jamur yang dapat tumbuh baik pada suhu kamar. Suhu optimum untuk kebanyakan jamur terutama jamur Candida albicans adalah sekitar $25-30^{\circ} \mathrm{C}$.

Pengujian aktivitas infusa daun sirsak terhadap jamur Candida albicans dilakukan dengan metode dilusi. Ada atau tidaknya aktivitas anti jamur dapat dilihat dari tingkat kekeruhan pada tabung percobaan yang kemudian ditetapkan sebagai Konsentrasi Hambat Minimal (KHM), kemudian dari hasil tersebut pada tabung yang jernih dilakukan goresan untuk ditetapkan sebagai Konsentrasi Bunuh Minimal (KBM).

Pada penelitian ini dilakukan uji aktivitas daun sirsak terhadap Candida albicans. Metode yang digunakan adalah dilusi. Metode dilusi (pengenceran) berdasarkan pengamatan kekeruhan larutan. Metode ini dapat menentukan secara kuantitatif konsentrasi terkecil suatu obat yang dapat menghambat pertumbuhan kuman. Prinsip dari metode dilusi adalah penghambatan pertumbuhan kuman dalam pembenihan (medium) cair oleh suatu obat yang dicampur ke dalam pembenihan. Pembenihan yang dipakai harus dapat menumbuhkan kuman secara optimal dan tidak menetralkan obat yang digunakan. Keuntungan metode dilusi adalah hasil yang didapat akurat, dan bisa dipakai untuk menguji aktivitas/sensitifitas infusa sampai konsentrasi terkecil. Sedangkan 
metode difusi hanya dapat diperoleh zona radikal (membunuh) dan irradikal (menghambat).

Hasil penelitian seperti yang tercantum pada tabel 1, menunjukkan bahwa semakin rendah konsentrasi infusa daun sirsak maka larutan semakin keruh (+). Kekeruhan suspensi pada tabung reaksi menunjukkan adanya pertumbuhan Candida albicans, semakin keruh suspensi berarti semakin banyak Candida albicans yang tumbuh. Pada penelitian ini menunjukkan semakin rendah konsentrasi infusa daun sirsak semakin rendah aktivitas hambat dan bunuh terhadap Candida albicans.

Konsentrasi hambat minimum ditunjukkan pada konsentrasi terkecil infusa daun sirsak pada tabung reaksi yang jernih dan jika diperlakukan inokulasi pada medium Sabouraud Glucose Agar padat akan tumbuh koloni. Konsentrasi bunuh minimum ditunjukkan pada konsentrasi infusa daun sirsak yang jernih jika dilakukan perataan pada medium Sabouraud Glucose Agar tidak di tumbuhi jamur uji.

Tabung reaksi yang berisi infusa daun sirsak dengan konsentrasi 50\%, 25\%, $12,5 \%$ dan suspensi Candida albicans, setelah diinkubasi 5 hari tetap jernih dan setelah dilakukan perataan pada media SGA tidak tumbuh koloni. Sedangkan pada tabung reaksi yang berisi suspensi jamur dan infusa daun sirsak dengan konsentrasi $6,25 \%, 3,13 \%, 1,56 \%, 0,79 \%$, $0,40 \%, 0,20 \%$ dan $0,10 \%$, larutan menjadi coklat keruh setelah diinkubasi pada waktu yang sama. Hal ini membuktikan bahwa ekstrak infusa daun sirsak mempunyai aktivitas hambat minimum terhadap Candida albicans pada konsentrasi $12,5 \%$ dan aktivitas bunuh minimum Candida albicans pada konsentrasi $12,5 \%$.

Kemungkinan efek anti jamur infusa daun sirsak disebabkan karena adanya senyawa tanin, fitosterol, kalsium oksalat dan alkaloid murisine. Alkaloid murisine yang tergolong dalam senyawa fenol. Senyawa fenol dapat mengakibatkan denaturasi protein membran, kemudian senyawa ini bisa menembus nukleus dan menyebabkan degradasi protein nukleus yang mengakibatkan kematian sel (dalam hal ini sel Candida albicans). Tanin dalam daun ini diduga memiliki efektifitas dalam menghambat atau membunuh jamur Candida albicans. Tanin memiliki arti pertahanan bagi tubuh, membantu mengusir hewan pemangsa tumbuhan, mempunyai aktifvitas anti oksidan dan berkhasiat bagi antiseptik. Hal ini menyebabkan infusa daun sirsak berkhasiat sebagai antiseptik.

\section{KESIMPULAN DAN SARAN}

Dari hasil penelitian dapat disimpulkan bahwa 
1. Infusa daun sirsak mempunyai aktivitas untuk menghambat dan membunuh pertumbuhan jamur Candida albicans.

2. Infusa daun sirsak menunjukkan KHM dan KBM pada konsentrasi $12,5 \%$.

Saran untiuk penelitian ini diharapkan

1. Perlu dilakukan penelitian lebih lanjut untuk mengetahui daya anti jamur daun sirsak dengan penyarian metode yang lainnya.

2. Perlu dilakukan penelitian anti jamur infusa daun sirsak terhadap jamur patogen lainnya yang dapat menginfeksi manusia.

\section{DAFTAR PUSTAKA}

Anonim, 2006. Pengenceran Dilusi, http://www.frachdie.blogsome.com diakses tanggal 15 januari 2011

Hutapea, J.R, (1991), Inventaris Tanaman Obat Indonesia, BPTO, Jakarta.

Kusuma, W. H., Wirian A.S., Dalimarta, S. 1992. Tanaman Berkhasiat Obat Di Indonesia. Jakarta: Jilid II, Pustaka Kartini.

Pelczar dan Chan. 1986. Dasar-dasar Mikrobiologi. Jakarta : Universitas Indonesia.

Radi, Juhaeni. 1996. Budidaya dan Pemanfaatan Sirsak. Bandung, Kanisius.

Robinson, T.,1995, The Organic Contituent of Higher Plant, 5 th ed, diterjemahkan oleh Kokasih
Anonim, 2010. Khasiat dan manfaat buah sirsak.

http://www.dalimunthe.com/ 2010/02/inilah-khasiat-buahsirsak.html diakses tanggal 25 november 2010

Anonim, 2011. Alkaloid pada Tumbuhan. http://id.wikipedia.org. diakses tanggal 18 januari 2011

Depkes, 1979. Farmakope Indonesia, Edisi III. Jakarta, Departemen Kesehatan Republik Indonesia.

Depkes, 1986. Sediaan Galenik. Jakarta, Departemen Kesehatan Republik Indonesia

Dwijoseputro, D., 1976. Pengantar Mikologi. Malang : Universitas Brawijaya

Frosbisher and Fuerst, 1983. Microbiology healty and Disease, $15^{\text {th }}$ Edition, Igokushian Saunders, International edition, 560-566

Harapan, M. 1984. Penyakit Menular Seksual, 106-111. Jakarta, Gramedia.

Padmawinata, Penerbit ITB, Bandung, 191-193, 208

Suprihatin, S.D. 1982. Candida dan Candidiasis pada Manusia. Jakarta: Fakultas Kedokteran,UI. Press

Siregar, (1995), Penyakit Jamur Kulit, 2829, FK UNSRI, EGC, Jakarta.

Thomas, A.N.S, 1992. Tanaman Obat Tradisional 2. Bandung, Kanisius. 